\title{
Assessment of bacteriological quality of groundwater from boreholes in Maroua (Far North Cameroon)
}

\author{
Moussa DJAOUDA ${ }^{1 *}$, Alain LECKÉ ${ }^{1}$, Mathieu Kalwé MAÏNÉ ${ }^{1}, Z_{\text {Zoua WADOUBÉ }}$, \\ Song LIANG ${ }^{3,4}$, Moïse NOLA ${ }^{5}$ and Thomas NJINÉ ${ }^{5}$ \\ ${ }^{1}$ Higher Teachers' Training College, University of Maroua, PO Box 55 Maroua, Cameroon. \\ ${ }^{2}$ Faculty of Science, University of Maroua, PO Box 814 Maroua, Cameroon. \\ ${ }^{3}$ Emerging Pathogens Institute, University of Florida, Gainesville, FL 32610, USA. \\ ${ }^{4}$ Department of Environmental and Global Health, College of Public Health and Health Professions, \\ University of Florida, Gainesville, FL 32610,USA. \\ ${ }^{5}$ Laboratory of General Biology, University of Yaoundé I, PO Box 812 Yaoundé, Cameroon. \\ *Corresponding author, E-mail: djoubei@gmail.com, Tel:+237 6997580 00/675 650086
}

\section{ACKNOWLEDGMENTS}

This research was partially supported by the International Foundation for Science, Stockholm, Sweden through a grant (W/5581-1).

\begin{abstract}
Groundwater (e.g. from wells and boreholes) represents an important source for water supply for populations in Maroua, Far north Cameroon. Although its consumption is being accentuated by the limited access to potable water, the quality of water from boreholes is unknown by the consumers. This study aimed at assessing the bacteriological quality of groundwater from boreholes in Maroua, in order to determine the impact of anthropogenic pressure and to measure the sanitary risks to which people who use them as drinking water sources are exposed. A total of 18 boreholes were chosen as sampling sites for bimonthly analyses (from October 2016 to January 2017). Microbiological analyses comprised the prevalence of total coliforms (TCs), Escherichia coli and Heterotrophic Aerobic and Mesophilic Bacteria (HAMB). Some physico-chemical parameters including temperature, $\mathrm{pH}$, electrical conductivity, total dissolved solids (TDSs), salinity, dissolved $\mathrm{CO}_{2}$ were measured to characterize these waters and to determine their influence on the bacterial flora. The results showed that the $\mathrm{pH}$ of the water of the 18 boreholes varied from 6.3 to $7.5 \mathrm{CU}$; the lower value of temperature was $25.9^{\circ} \mathrm{C}$ and the higher was $31.2{ }^{\circ} \mathrm{C}$. The values of electrical conductivity, TDSs and Salinity fluctuated from 171.5 to $1910.3 \mu \mathrm{S} / \mathrm{cm}, 119.4$ to $1331.3 \mathrm{mg} / \mathrm{l}$ and 79.2 to $970.3 \mathrm{ppm}$ respectively in the water samples of these boreholes. The concentration of dissolved $\mathrm{CO}_{2}$ varied from 9.5 to $27.8 \mathrm{mg} / \mathrm{l}$ of water. From these results, $72.2 \%$ of analysed water samples were contaminated by the total coliforms and $E$. coli. The water contamination would be the consequence of the proximity of boreholes with latrines and domestic wastes. There is a need to educate the public about the quality of their water sources and the importance of clean and healthy surroundings near water sources and to implement household water treatment to improve the water quality and reduce waterborne diseases.
\end{abstract}

(C) 2018 International Formulae Group. All rights reserved.

Keywords: Bacteria, contamination, groundwater, sanitation. 


\section{INTRODUCTION}

Waterborne diseases constitute a serious public health problem in developing countries. In low and middle income nations, $58 \%$ of all diarrheal disease-related deaths are caused by inadequate access to safe water, poor hygiene, and unimproved sanitation conditions (WHO, 2014). In Cameroon, waterborne diseases due to bacteria are common. Diarrhoeal diseases were estimated to cause 15 to $20 \%$ of deaths annually (Ngwe and Banza-Nsungu, 2007). Cholera is nearly endemic in far north region of this country (Arabi et al., 2014).

Drinking water quality, high population densities, resulting from uncontrolled urbanization, coupled with poor hygiene and inadequate sanitation facilities play an important role in the emergence and transmission of waterborne diseases in urban environment (Sobsey, 2002; Negera et al., 2017). In Maroua, as in many cities of Cameroon, people use several types of water supplies according to their income. The households with higher incomes have access to potable water from taps whereas the poor (majority) are forced to get drinking water from public or private boreholes, wells, and even from streams and rains (Gorham et al., 2017). Leaning on organoleptic criteria and their localization in soil, these households think that borehole waters are drinkable and free from contamination (unpublished data).

However, boreholes are often badly maintained or non-protected and water that they get is sometimes contaminated (Amadou et al., 2014). The pollution of groundwater is generally increased by several human factors such as defecation in nature, presence of pit latrines, waste water, agricultural activities, farms and discharges of chemicals, in industrial sites, close to water points (Kirschnner et al., 2009). These factors could have considerable impacts on the quality of boreholes water. Studies showed that bacterial contamination of groundwater would be due to lack of sanitation system, poor habits in management of wastes and the presence of latrines close to water sources (Djaouda et al., 2014; Dovonou et al., 2017).

Microbiological pollution of water sources is often determined by counting faecal bacteria considered as bio-indicators such as coliforms and E. coli (Ashbolt et al., 2001; APHA, 2012). This is due to the fact their population is proportional to the amount of feces entering into environment (Páll et al., 2013). The enumeration of Heterotrophic Aerobic and Mesophilic Bacteria (HAMB) informs on the general microbiological quality of water. This bacterial group contains the following taxa: Aeromonas, Enterococcus, Bacillus, Pseudomonas, Klebsiella, Flavobacterium, Citrobacter, Serratia, Acinetobacter, Proteus, Alcaligenes, Enterobacter and Moraxella (Gerba, 2009). Generally, these bacteria are not pathogenic, but among them opportunistic pathogens which may have impacts on human health, especially in immunocompromised populations, children and old persons consuming soiled water, can be found (Bartram et al., 2003). The development of the microbial communities in surface water and groundwater would be related to meteorological factors, physico-chemical and biological characteristics of the biotope (Hounsounou et al., 2016).

In Maroua, where epidemics of cholera frequently take place (Healy Profitos et al., 2014), borehole water is extensively used as drinking water. In addition, several non governmental Organizations through their programs contribute to fight against poverty and waterborne diseases by constructing many boreholes, with different management levels, as an alternative water resource to the use of well water and stream water in Maroua. Unfortunately numerous activities likely to compromise the quality of borehole water are 
found at the borehole surroundings. The aim of this study was to evaluate the bacteriological quality of borehole waters intended to the consumption in Maroua, in order to determine the impact of anthropogenic pressure and to measure the sanitary risks to which people who use them as drinking water sources are exposed.

\section{MATERIALS AND METHODS}

\section{Description of the study site}

Maroua, the most important city of the Far North region of Cameroon, is located at $400 \mathrm{~m}$ asl altitude, $10^{\circ} 29^{\prime}$ to $10^{\circ} 41^{\prime} \mathrm{N}$ latitude and $14^{\circ} 15^{\prime}$ to $14^{\circ} 27^{\prime} \mathrm{E}$ longitude. This city has an area of $56 \mathrm{~km}^{2}$ and a population estimated to 201371 inhabitants (BUCREP, 2017). The climate is typical sudano-sahelian with two seasons: dry season (October to May) and rainy season from June to September with an average annual precipitation of $811.6 \mathrm{~mm}$ per year. Annual temperature ranges between $20{ }^{\circ} \mathrm{C}$ and $45^{\circ} \mathrm{C}$ with an average of $28.3^{\circ} \mathrm{C}$. March, April and May are the hottest months of the year, while December, January and February are cold with average temperature ranging from 26 to $28{ }^{\circ} \mathrm{C}$. Soils texture varies from clayey to sandy-clayey and sandy-slimy. The hydrology of this city is governed by the Kaliao and Tsanaga sub-basins, tributaries of the lake Chad basin. All the rivers of these sub-basins have non-permanent out-flows (Sighomnou et al., 2002).

\section{Sampling sites}

A census of boreholes has been made within the period from September to November 2016 in Maroua. Direct observation and inquiry were conducted to collect some information on the boreholes as: the type of borehole pump, owner, locations, use of water, outside aspect or environment of borehole. A total of 215 boreholes have been identified among which 35 are out-of-use. For multiple reasons such as insufficiency of funds, high number of boreholes, we sampled a subset of the boreholes. The selection was based on the nearness to a potential source of water contamination, type of borehole pump (mechanic or electric) (Figure 1) and type of borehole (private or public). In addition, geographical location was considered to attain good spatial representation.

Eighteen (18) boreholes (15 boreholes with human motricity and three boreholes with electric pump) have been chosen among the 180 functional boreholes. They have been coded F1 to F18 (Figure 2).

A hand-held GPS (Garmin brand) has been used for the location of these sampling sites. The characteristics of the sampled boreholes arisen from the criteria used for their selection were documented (Table 1).

\section{Water sample collection}

The collection of water samples from each borehole was made according to a bimonthly frequency from October 2016 to January 2017. At each sampling point, two water samples were collected, one in a $500 \mathrm{ml}$ sterile glass bottle and the other in a $1,000 \mathrm{ml}$ polyethylene bottle. All collected samples were kept at $4{ }^{\circ} \mathrm{C}$ and analysed within $2 \mathrm{~h}$ of collection. The sample in sterile glass bottle was used for bacteriological analysis and the other, in the polyethylene bottle, for physicochemical analysis (APHA, 2012).

\section{Water analyses \\ Physico-chemical analysis}

The physico-chemical parameters considered were $\mathrm{pH}$, electrical conductivity, temperature, total dissolved solids (TDSs), salinity and dissolved carbon dioxide. These parameters were chosen in accordance with their general importance in bacterial metabolism and the availability of our laboratory equipment. Temperature, $\mathrm{pH}$, electrical conductivity, TDSs and salinity 
were measured using a portable $\mathrm{pH} /$ conductivity/TDS/salinity meter, Extech EC500. Calibration and standardization of apparatus were performed according to the manufacturer's instructions before in situ use. The estimation of dissolved carbon dioxide $\left(\mathrm{CO}_{2}\right)$ was done by titrimetric method using a slight excess of sodium hydroxide solution $(0.025 \mathrm{~N})$, checked by means of phenolphthalein indicator, to neutralize the carbon dioxide immediately after water sampling, and titration with hydrochloric acid solution $(0.02 \mathrm{~N})$ was carried out later in the laboratory (Rodier, 2009). Two sets of samples were collected at each site for physico-chemical analysis.

\section{Bacteriological analysis}

Heterotrophic bacteria were enumerated using the spread plate method with plate count agar (Bio-Rad, France). 0.1 $\mathrm{ml}$ raw/diluted water sample was pipetted onto the surface of a plate count agar in sterile $90 \times 15 \mathrm{~mm}$ petri dishes (Gosselin a Corning Brand, France). Inoculum was spread using a bent glass rod over the surface of the plate. Inoculum was let being absorbed completely into the medium before incubating at $37{ }^{\circ} \mathrm{C}$ for $72 \mathrm{~h}$. Two repetitions were done using dilutions in order to select the plate that contains 30-300 CFU. The counting of colonies was performed using a colony counter (Jouan CC120, France) according to recommendations from APHA (2012). Membrane filtration was used to enumerate qualitative microbial indicators [total coliforms (TCs) and Escherichia coli] according to the standard methods (APHA, 2012). For each borehole, raw/diluted water sample was filtered through a sterile $47 \mathrm{~mm}$, $0.45 \mu \mathrm{m}$-pore-diameter, gridded membrane filter, under partial vacuum. Funnel was rinsed with three $30 \mathrm{ml}$ portion of sterile dilution water. Filter was removed with a sterile forceps and placed on agar in $55 \times 9 \mathrm{~mm}$ petri dish (Gosselin a Corning Brand, France). The
m-Endo LES (Difco Laboratories, Detroit, MI, USA) agar was used for the enumeration of TCs and E. coli, after $24 \mathrm{~h}$ incubation at 37 and $44{ }^{\circ} \mathrm{C}$, respectively. The typical coliform colony on m-Endo has a pink to dark-red colour with a metallic surface sheen. The resulting metallic green sheen colony forming unit (CFU) were subsequently identified according to Holt et al. (2000). The identification of each $E$. coli colony was confirmed using API $10 \mathrm{~S}$ system after a subculture on a standard agar medium. Gramstain, catalase and oxidase were confirmed before inoculating a test strip. API test strip consists of microtubes (cupules) containing dehydrated substrates to detect the enzymatic activity by the inoculated organisms. During incubation $\left(24 \mathrm{~h}\right.$ at $\left.37{ }^{\circ} \mathrm{C}\right)$, metabolism produces colour changes that are either spontaneous or revealed by the addition of reagents. Test results are entered into an online database to determine the bacterial identity.

\section{Statistical analysis}

Data collected were entered in Excel Spreadsheet. Changes in bacterial densities and physicochemical parameters of water at the different sampling sites were plotted using the SigmaPlot 10.0 software. Due to their skewed distributions, physico-chemical data and the bacterial counts were log-transformed. A principal component analysis (PCA) was performed using normalized average microbiological and physico-chemical data of the 18 boreholes. PCA was used to study the relationship between microbiological and physicochemical parameters. In PCA, factors were identified via varimax rotation with eigenvalue $>1$. To classify the sampling sites according to the properties of their water samples, a hierarchical cluster analysis (HCA) of water points was conducted. These two analyses were applied using the software XLSTAT 2007. 

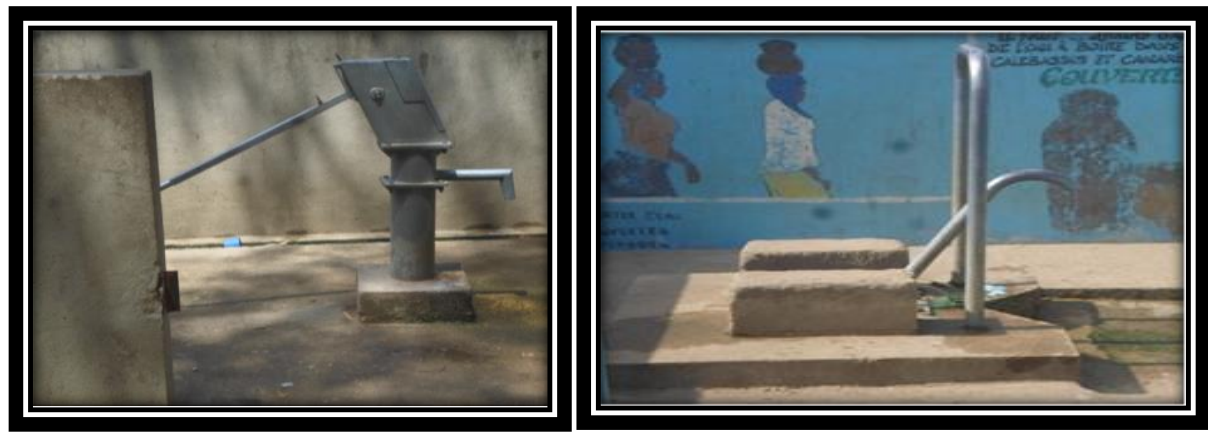

a

$\mathrm{b}$

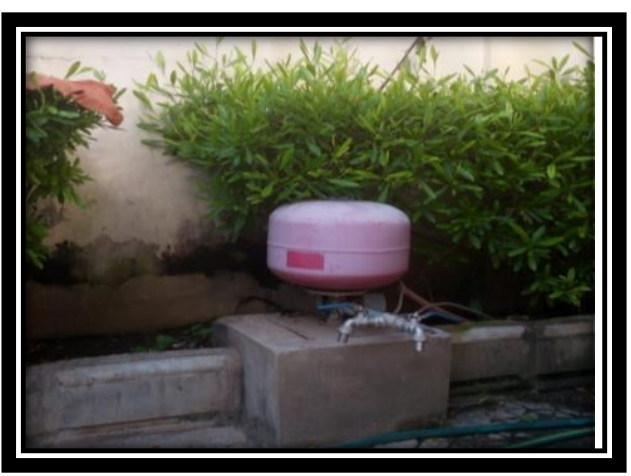

c

Figure 1: Pictures of the different types of borehole pumps (a: hand pump, b: pedestrian pump, c: electric pump).

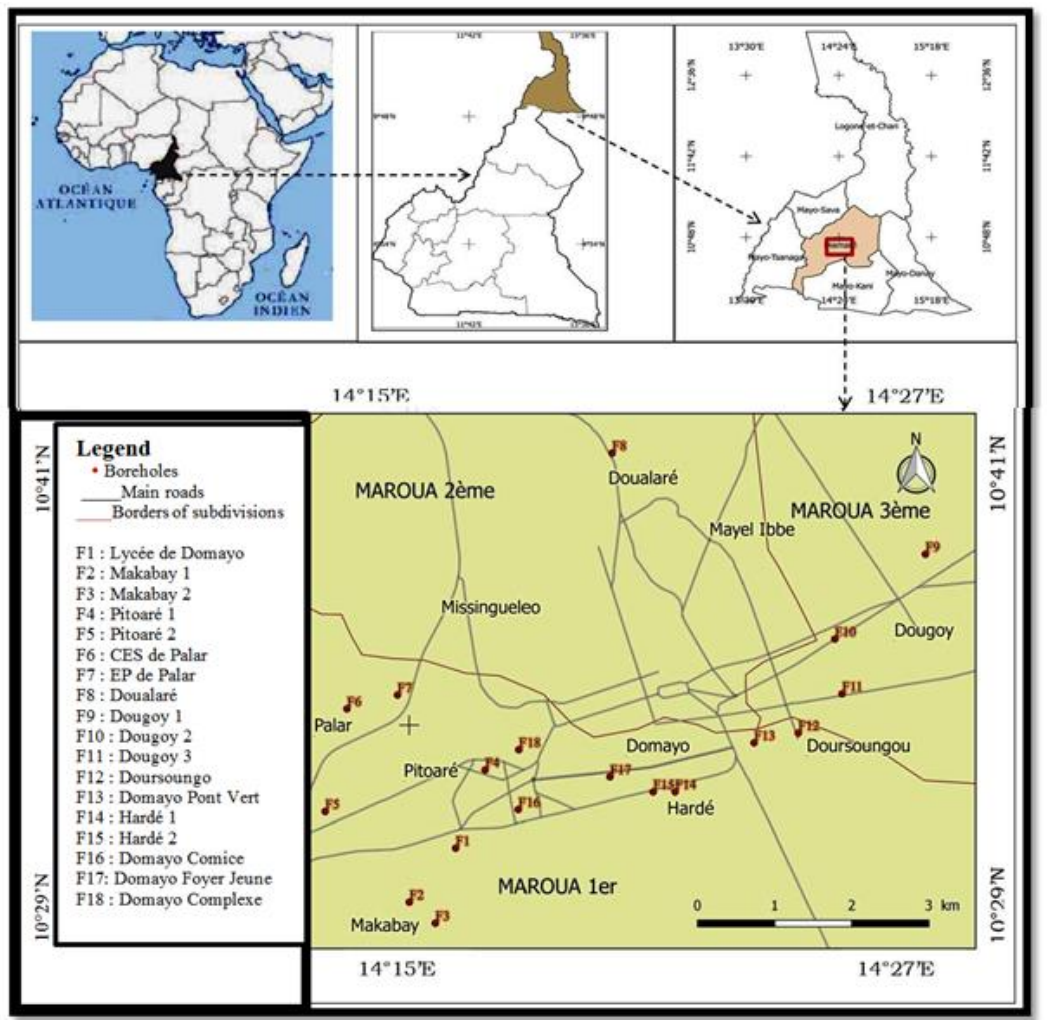

Figure 2: Map of Maroua city showing the locations of the sampling sites. 
Table 1: Characteristics of sampled boreholes.

\begin{tabular}{|c|c|c|c|c|c|c|c|}
\hline Boreholes & Quarters & $\begin{array}{r}\text { Type of } \\
\text { borehole }\end{array}$ & Type of pump & Potential source of pollution & $\begin{array}{c}\text { Obvious } \\
\text { Healthiness }\end{array}$ & $\begin{array}{c}\text { Altitude } \\
\text { (m) asl }\end{array}$ & $\begin{array}{l}\text { Number of users } \\
\text { during one hour }\end{array}$ \\
\hline F1 & Domayo & Public & Human motricity & Stagnant water at $5 \mathrm{~m}$ & Dirty & 383 & 388 \\
\hline $\mathrm{F} 2$ & Makabaye & Public & Human motricity & Stagnant water à $1 \mathrm{~m}$, mayo at $35 \mathrm{~m}$, latrines at $12 \mathrm{~m}$ & Very dirty & 393 & 26 \\
\hline F3 & Makabaye & Public & Human motricity & latrines at $9 \mathrm{~m}$ & Dirty & 378 & 11 \\
\hline $\mathrm{F} 4$ & Pitoaré & Pivate & Human motricity & Septic tank at $2 \mathrm{~m}$ & Dirty & 388 & 01 \\
\hline F5 & Pitoaré & Public & Human motricity & Latrines at $12 \mathrm{~m}$, gullies at $2 \mathrm{~m}$, pit at $3 \mathrm{~m}$ & Very dirty & 392 & 19 \\
\hline F6 & Palar & Public & Human motricity & None & Clean & 396 & 78 \\
\hline F7 & Palar & Public & Human motricity & Stagnant water at $2 \mathrm{~m}$, latrines at $15 \mathrm{~m}$ & Very dirty & 396 & 97 \\
\hline F8 & Doualaré & Public & Human motricity & Stagnant water at $04 \mathrm{~m}$, pit at $5 \mathrm{~m}$ & Very dirty & 402 & 32 \\
\hline F9 & Dougoy & Public & Human motricity & Gullies at $1 \mathrm{~m}$, latrines at $11 \mathrm{~m}$, garbages at $4 \mathrm{~m}$ & Very dirty & 381 & 13 \\
\hline F10 & Dougoy & Public & Human motricity & Gutters at $1 \mathrm{~m}$, latrines at $8 \mathrm{~m}$, domestic wastes at $3 \mathrm{~m}$ & Very dirty & 383 & 09 \\
\hline F11 & Dougoy & Private & electric & Latrines at $3 \mathrm{~m}$ & Dirty & 382 & 01 \\
\hline F12 & Doursoungo & Public & Human motricity & Septic tank at $5 \mathrm{~m}$, mayo at $50 \mathrm{~m}$, Stagnant water at $1 \mathrm{~m}$ & Very dirty & 398 & 12 \\
\hline F13 & Domayo & Public & Human motricity & Stagnant water at $2 \mathrm{~m}$, latrines at $15 \mathrm{~m}$, garbages at $4 \mathrm{~m}$ & Very dirty & 383 & 32 \\
\hline F14 & Hardé & Private & electric & Latrines at $2 \mathrm{~m}$ & Dirty & 381 & 12 \\
\hline F15 & Hardé & Public & Human motricity & Stagnant water at $3 \mathrm{~m}$, garbages at $2 \mathrm{~m}$, latrines at $20 \mathrm{~m}$ & Very dirty & 380 & 25 \\
\hline F16 & Domayo & Public & Human motricity & Latrines at $15 \mathrm{~m}$, pits at $5 \mathrm{~m}$, garbages at $02 \mathrm{~m}$ & Very dirty & 388 & 14 \\
\hline F17 & Domayo & Public & Human motricity & Stagnant water at $01 \mathrm{~m}$, gutters at $01 \mathrm{~m}$, garbages at $08 \mathrm{~m}$ & Very dirty & 399 & 06 \\
\hline F18 & Domayo & Private & electric & Latrines at $3 \mathrm{~m}$, mayo at $40 \mathrm{~m}$, gutters at $5 \mathrm{~m}$, wastes at $30 \mathrm{~m}$ & Very dirty & 389 & 19 \\
\hline
\end{tabular}




\section{RESULTS}

The results of the physico-chemical analysis are shown in Figures 3, 4, 5, 6, 7 and 8 . The water $\mathrm{pH}$ varied from one borehole to another (Figure 3). The $\mathrm{pH}$ values oscillated between $6.3 \mathrm{CU}$ (conventional unit) at borehole F9 (Dougoy) and 7.5 CU at borehole F2 (Makabaye). Boreholes which presented water samples with low $\mathrm{pH}$ values are located in Dougoy and Domayo quarters while boreholes in areas as Makabay, Hardé and Pitoaré generally have $\mathrm{pH}$ values above $7 \mathrm{CU}$. Electrical conductivity of the studied water (Figure 4) varied from $171.5 \mu \mathrm{S} / \mathrm{cm}$ at borehole F1 (Lycée Domayo) to 1910.3 $\mu \mathrm{S} / \mathrm{cm}$ at borehole F17 (Domayo). Boreholes F1, F2, F3, F5, F6, F7, F14, F15, F16 and F18 have electrical conductivity values lower than $400 \mu \mathrm{S} / \mathrm{cm}$. The values of temperature of borehole waters presented variation according to boreholes (Figure 5). These values varied from $25.9^{\circ} \mathrm{C}$ at borehole F2 (Makabaye) to $31.2^{\circ} \mathrm{C}$ at borehole F15 (Hardé). Sampling hour and location of borehole in relation with shade would have influenced the temperature of water. TDSs levels of water samples varied from one borehole to another (Figure 6) between $119.4 \mathrm{mg} / \mathrm{l}$ at borehole $\mathrm{F} 1$ and 1331.3 $\mathrm{mg} / \mathrm{l}$ at borehole F17. The values of TDSs of 13 boreholes (F1, F2, F3, F4, F5, F6, F7, F11, F12, F14, F15, F16 and F18) were lower than $500 \mathrm{mg} / \mathrm{l}$. Boreholes F8, F9, F10, F13 and F17 had TDSs levels above WHO standard for drinking water. Like electrical conductivity, TDSs were not coupled to boreholes characteristics considered in this survey. The concentration of dissolved carbon dioxide in water samples varied from $9.5 \mathrm{mg} / \mathrm{l}$ at borehole F2 (Makabaye) to $27.8 \mathrm{mg} / \mathrm{l}$ at borehole F4 (Pitoaré). The fluctuations of this parameter according to sampling days were also important (Figure 7). The water salinity oscillated from $79.2 \mathrm{ppm}$ at borehole $\mathrm{F} 1$ to $970.3 \mathrm{ppm}$ at borehole F17 (Figure 8). The values of salinity of 10 boreholes (F1, F2, F3, F5, F6, F7, F14, F15, F16 and F18) were lower than $200 \mathrm{ppm}$. The variation of salinity was in agreement with that of TDSs and electrical conductivity.
The bacterial abundances of water samples varied from one borehole to another. Figure 9 shows the fluctuations of the abundance of E. coli according to the boreholes. This abundance fluctuated between 0 CFU/100ml at boreholes F1 (Domayo), F4 (Pitoaré), F6 (Palar), F9 (Dougoy) and F17 (Domayo) and $172 \mathrm{CFU} / 100 \mathrm{ml}$ at borehole F3 (Makabaye). These results showed that $72.22 \%$ of boreholes are contamined by $E$. coli and are not in conformith with the WHO standard for drinking water, which is $0 \mathrm{CFU}$ of E. coli per $100 \mathrm{ml}$ of water. Only $27.77 \%$ borehole water samples were negative to $E$. coli. If the location within schools of boreholes F1 and F6 and the limitation of the access to public of borehole F4 reduced the influence of the polluting anthropogenic pressure on these boreholes, the abundance of E. coli of boreholes F9 and F17 seems surprising. The abundance of $E$. coli in water samples would be more related to the distance separating the borehole with potential source of contamination than all other potential factors. Abundance of total coliforms (Figure 10) ranged from $0 \mathrm{CFU} / 100 \mathrm{ml}$ at boreholes $\mathrm{F} 1$ (Domayo), F4 (Pitoaré), F6 (Palar), F9 (Dougoy) and F17 (Domayo) to $203 \mathrm{CFU} / 100$ $\mathrm{ml}$ at borehole F3 (Makabaye). $72.22 \%$ of boreholes were contaminated with total coliforms. The abundance of total coliforms was coupled to abundance of $E$. coli. The bacteriological quality of these borehole waters did not conform with the WHO standard for drinking water $(0 \mathrm{CFU} / 100 \mathrm{ml}$ of water). $27.77 \%$ of boreholes were negative to total coliforms. Abundance of HAMB in borehole water samples fluctuated from 23 $\mathrm{CFU} / \mathrm{ml}$ at borehole F12 (Domayo) to 155 $\mathrm{CFU} / \mathrm{ml}$ at borehole F10 (Dougoy) (Figure 11). This abundance did not exactly meet to that obtained for other measured bacteriological parameters.

Principal component analysis (PCA) and hierarchical cluster analysis (HCA) have been performed on data of all water parameters considered in this survey. Principal component analysis enabled to understand the structure of correlation of these 
parameters and to identify the most importants components contributing to this structure. Hierarchical cluster analysis contributed to reduce and group boreholes in classes having similar properties. Results of principal component analysis showed that electrical conductivity, salinity and TDSs are positively correlated to component F1 (42.98\%). pH is negatively correlated to this component (Figure 12). The F1 component represents the variations of physico-chemical parameters. It is related to mineralization and presence of inorganic salts in boreholes water. The component F2 $(29.07 \%)$ is determined by abundance of E. coli, total coliforms and HAMB. F2 component expresses the variations of the bacterial abundances of boreholes water. Figure 12 indicates that boreholes F9 and F17 are singularized by their high mineralization whereas the F3 and F10 boreholes were distinguished by their high contamination by bacterial germs counted during this survey. However, this analysis did not permit a combination of all parameters analyzed to get the groups of boreholes according to their characteristics.
The assessment of the quality of water samples has been made by categorizing sampled boreholes in similar zones. Figure 13 presents results of classification of the sampled points (boreholes). Four main classes were distinguished: $\mathrm{C} 1, \mathrm{C} 2, \mathrm{C} 3$ and $\mathrm{C} 4$. The analysis of Figures 12 and 13 has distinguished the characteristics and constitution of the four groups of boreholes observed:

- Class C1 boreholes (F1, F2, F3, F5, F6, F7, $F 14, F 15, F 16$ and F18) were characterized by lower values of electrical conductivity, TDSs and salinity;

- Class C2 boreholes (F4, F8, F11, F12 and F13) had low values of electrical conductivity, salinity and TDSs;

- Class C3 boreholes (F9 and F17) presented high values of electrical conductivity, of TDSs and salinity;

- Class C4 borehole (F10) presented high bacterial abundance, electrical conductivity, TDSs and salinity values. This borehole is located close to gutter, latrines and big waste dump.

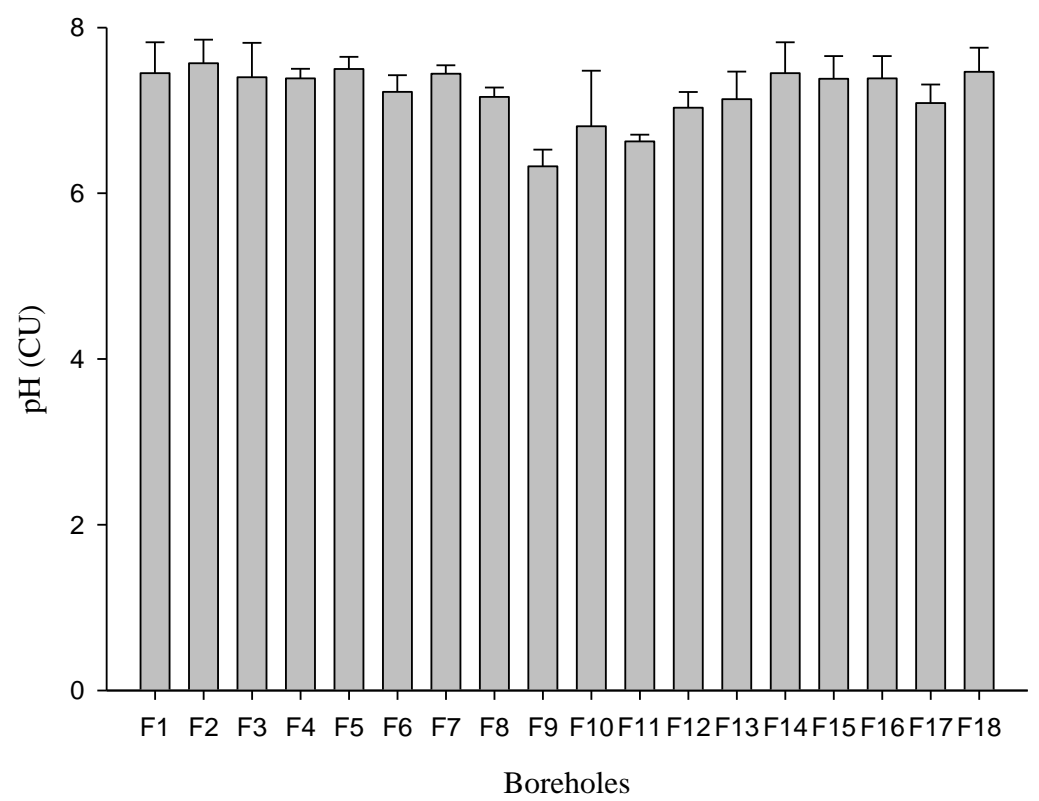

Figure 3: Variation with respect to the borehole of the average ( \pm standard error) values of water $\mathrm{pH}$. 


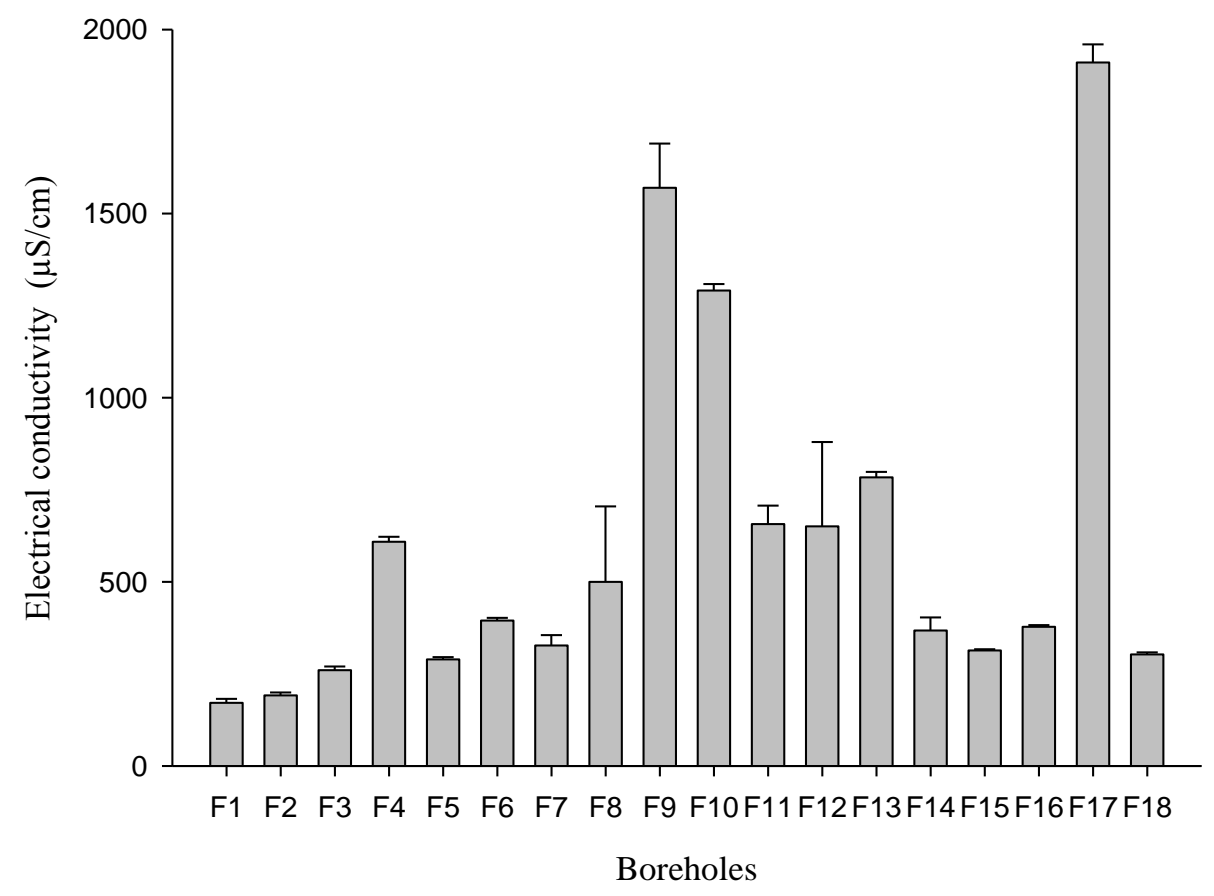

Figure 4: Variations of electrical conductivity (average \pm standard error) according to boreholes (F1 to F18).

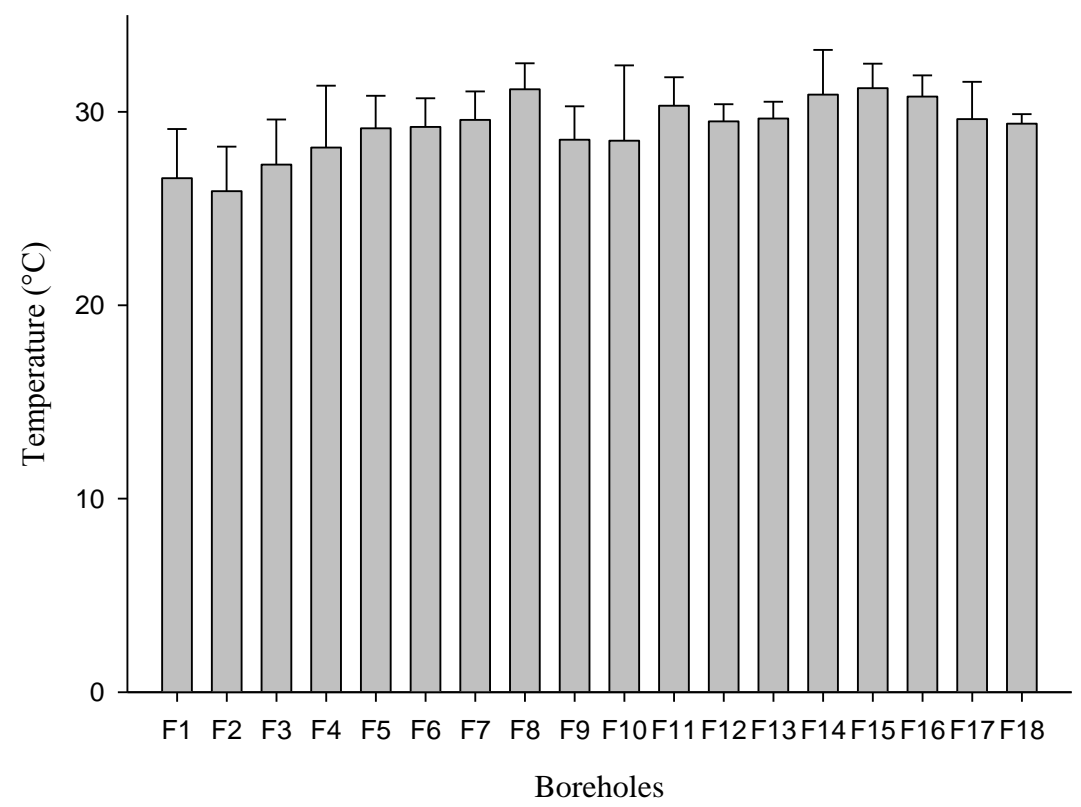

Figure 5: Variation of temperature (average \pm standard error) according to boreholes (F1 to F18). 


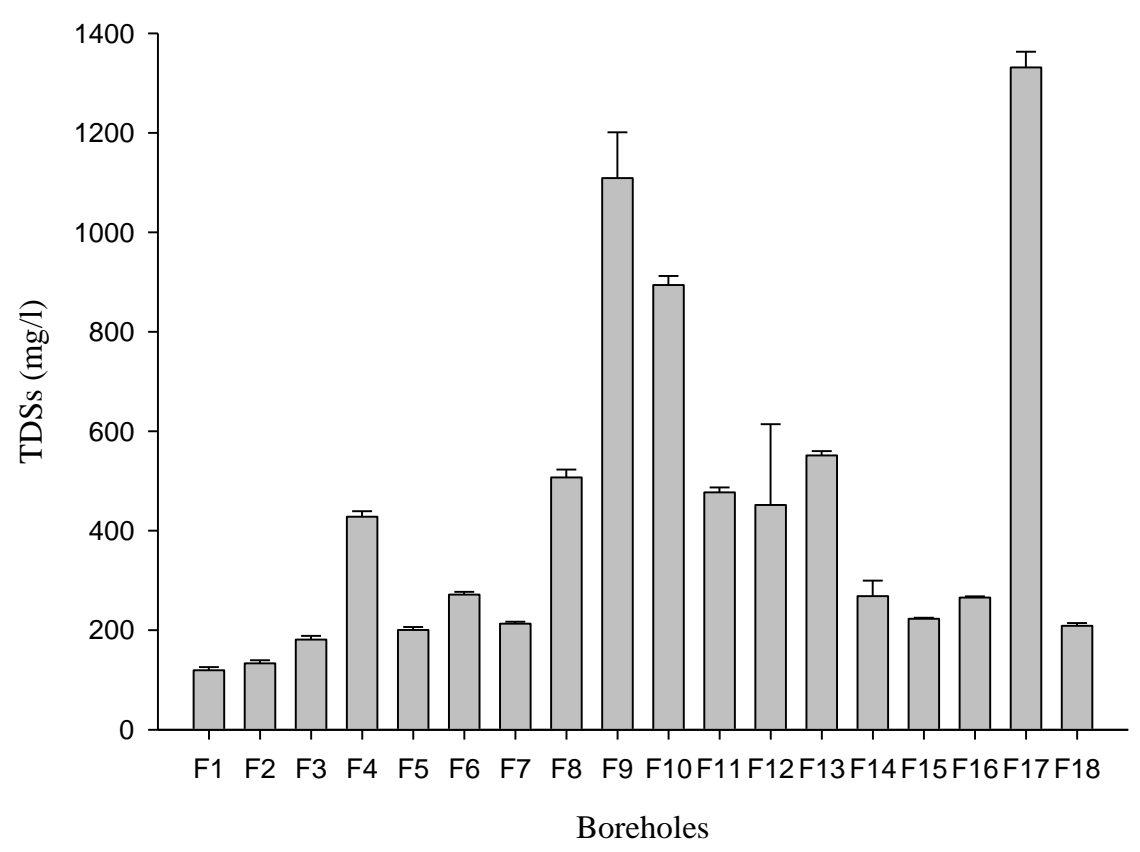

Figure 6: Variations of TDSs (average \pm standard error) according to boreholes (F1 to F18).

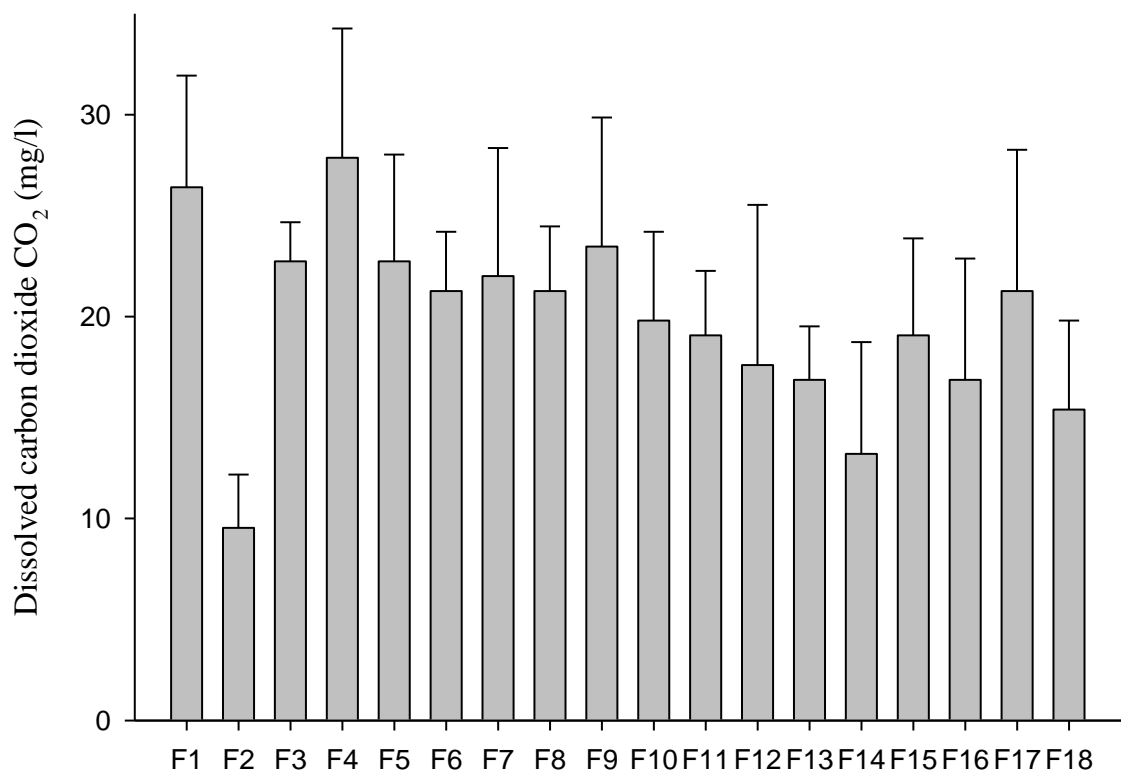

Boreholes

Figure 7: Variations of concentration of dissolved carbon dioxide (average \pm standard error) according to boreholes (F1 to F18). 


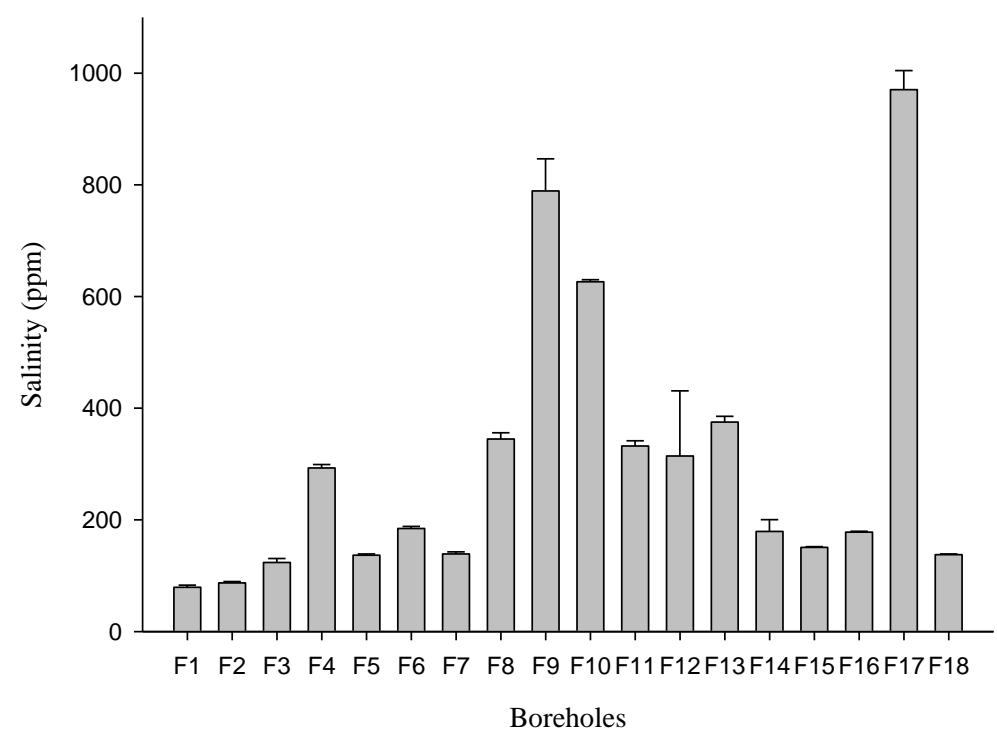

Figure 8: Variation of salinity (average \pm standard error) according to boreholes (F1 to F18).

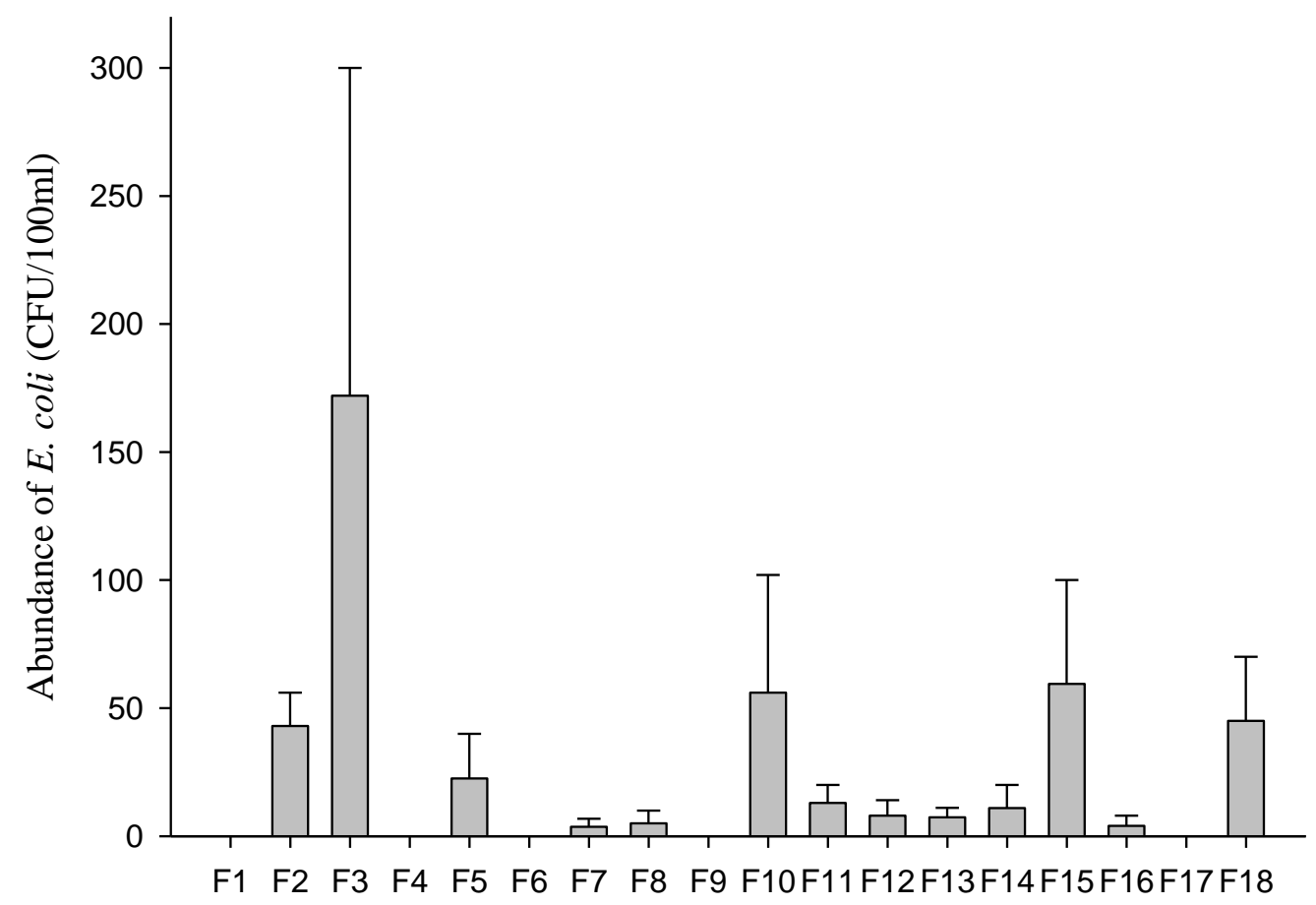

Boreholes

Figure 9: Variation of E. coli abundances (average \pm standard error) according to boreholes (F1 to F18). 


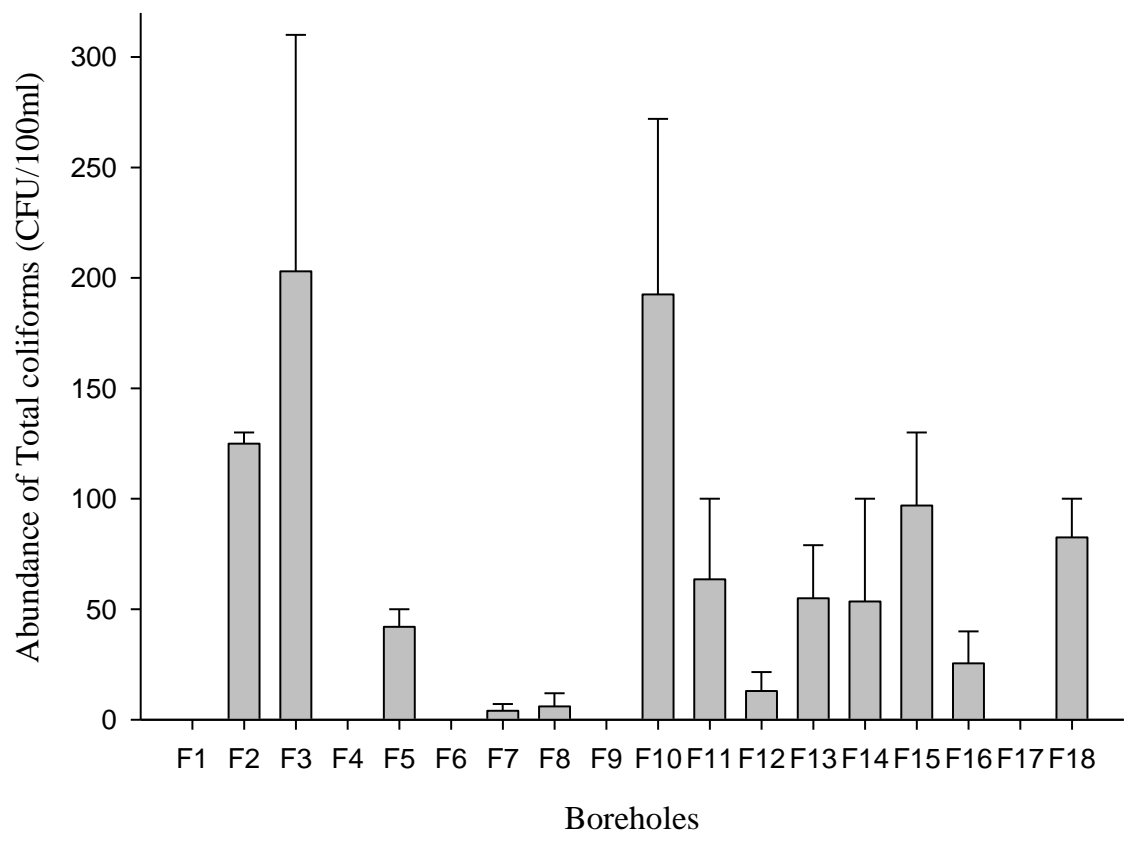

Figure 10: Variation of total coliforms abundance (average \pm standard error) according to boreholes (F1 to F18).

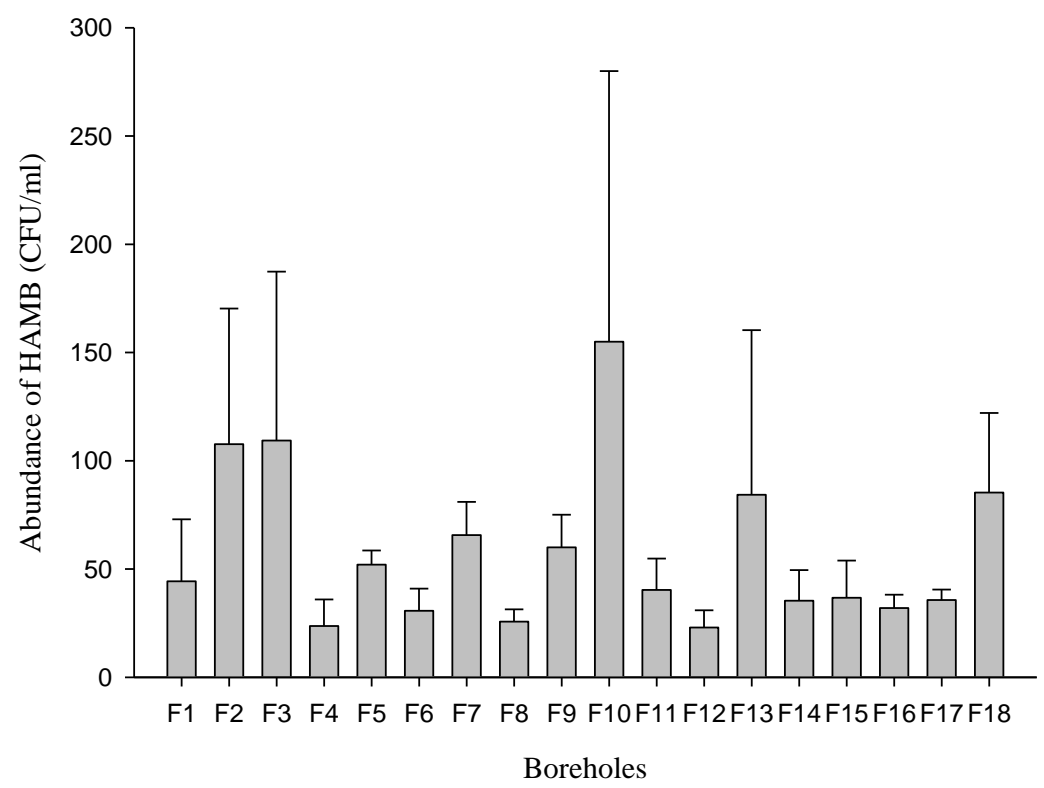

Figure 11: Variation of HAMB abundance (average \pm standard error) according to boreholes (F1 to F18). 


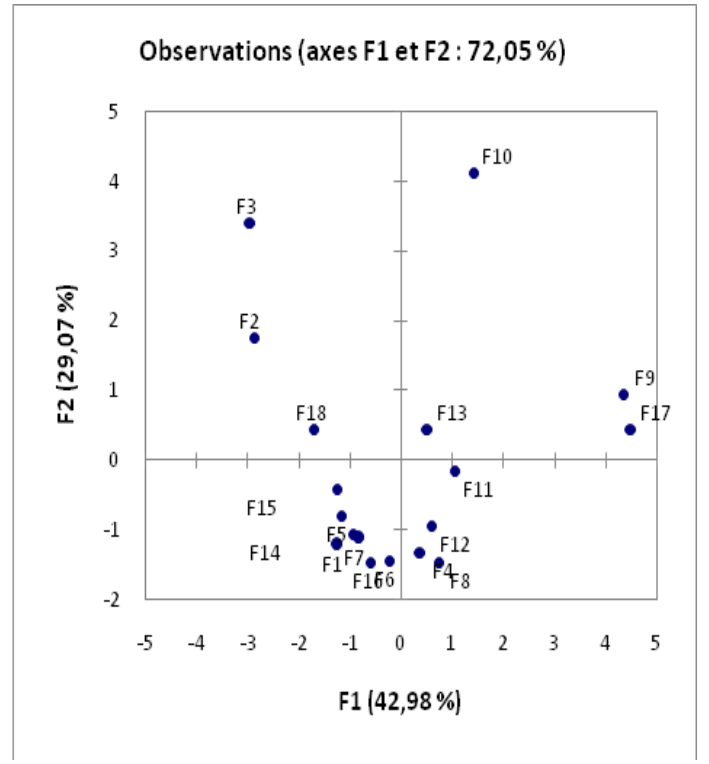

a)

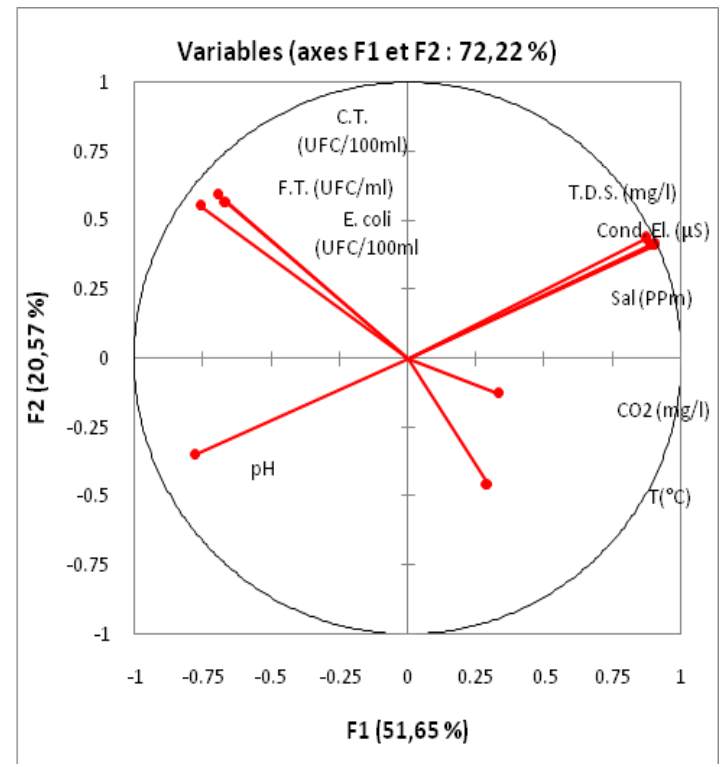

b)

Figure 12: Spatial variability of physico-chemical and bacteriological characteristics of borehole water of study sites. a) Projections of the boreholes (F1...F18), according to the measured physico-chemical and bacteriological variables, on the plane of the first two factorial axes of the PCA (axis 1 horizontal and axis 2 vertical). b) Projections of the physico-chemical variables of water samples collected on the plane of the first two axes of the PCA (axis 1 horizontal and axis 2 vertical). CT, FT, Cond. El, Sal, T is the abbreviation of total coliform, fecal coliform, heterotrophic aerobic and mesophilic bacteria, electrical conductivity, salinity and temperature, respectively.

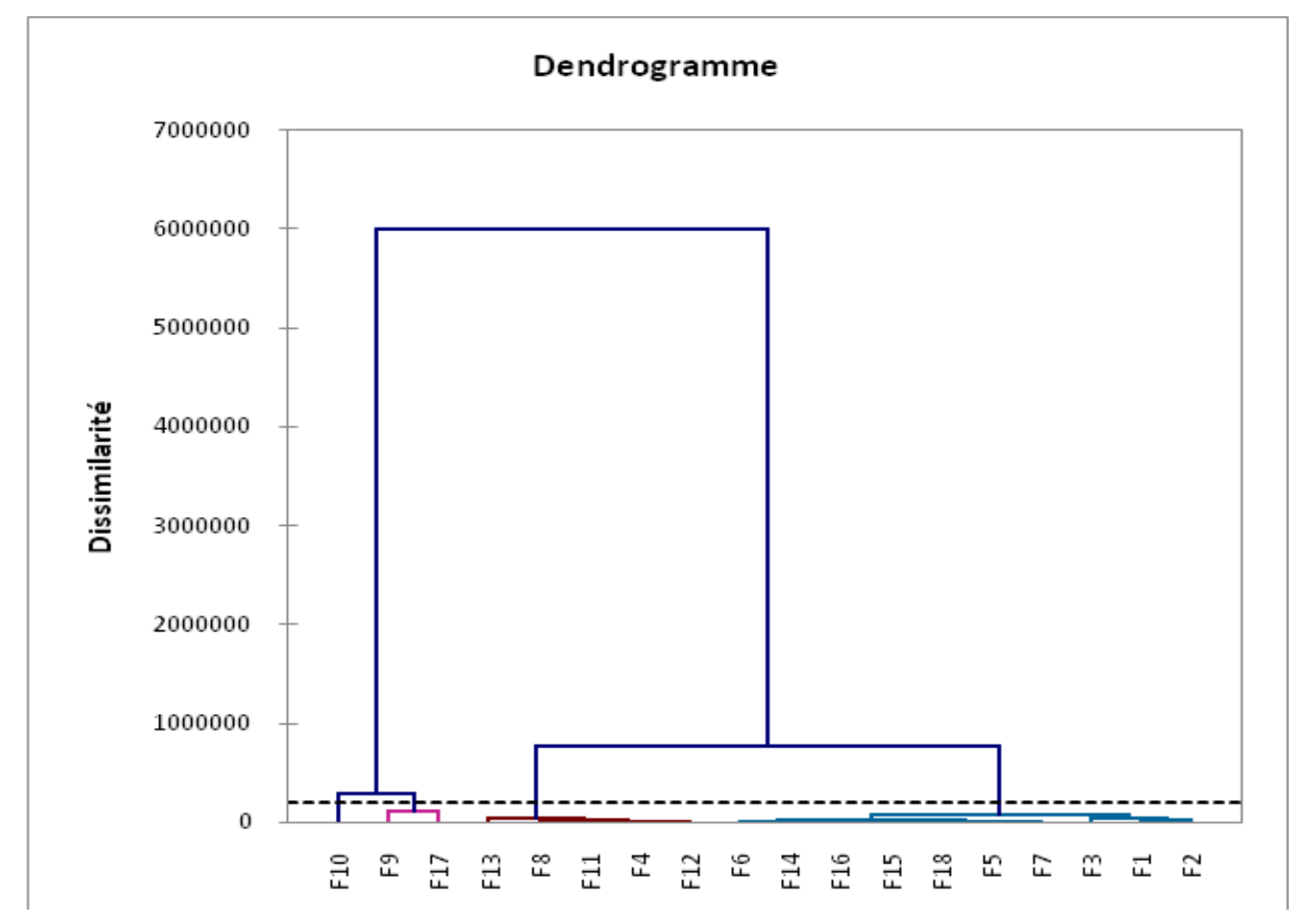

Figure 13: Dendrogram showing the hierarchical clusters of sampled boreholes. 


\section{DISCUSSION}

The $\mathrm{pH}$ of boreholes water ranged from 6.3 CU to 7.5 CU. Apart from borehole $\mathrm{F} 9$, the $\mathrm{pH}$ of different studied borehole waters presented values within acceptable WHO limits, between $6.5 \mathrm{CU}$ and $8.5 \mathrm{CU}$ (WHO, 2003). These values have been associated to the geographic location of the water point. The variations of $\mathrm{pH}$ values are likely accociated with the nature of the lands crossed because $\mathrm{pH}$ of groundwater is not different from the $\mathrm{pH}$ of crossed soil (Mkandawire, 2008; Nouayti et al., 2015). According to Djuikom (2006), the $\mathrm{pH}$ of water can also be influenced by the action of microorganisms and the proximity of latrines with water point. The electrical conductivity of borehole waters followed spatial variations. This mineralisation was low at borehole $\mathrm{F} 1$ $(171.5 \mu \mathrm{S} / \mathrm{cm})$ and high at borehole F17 $(1910.3 \mu \mathrm{S} / \mathrm{cm})$. The physical characteristics of the borehole do not seem to explain the mineralization obtained. The variations of electrical conductivity would result from the washing of the rock reservoir within which water stay (Mkandawire, 2008). According to Belghiti et al. (2013), the electrical conductivity depends on the loads of generating endogenous and exogenous organic matters, release of salts after mineralization and the evaporative system which concentrates these salts in water. It also varies according to the geological substratum crossed. According to Amadou et al. (2014), high values of the electrical conductivity could be explained by infiltration of waste water or wastes of the neighboring septic tanks in the water table. Therefore, distance between potential source of pollution and borehole would be determinant for the degree of water mineralization. In this survey, the minimal temperature of water was $25.9^{\circ} \mathrm{C}(\mathrm{F} 2$ borehole) and the maximum was $31.2^{\circ} \mathrm{C}(\mathrm{F} 15$ borehole). All these values were above the drinking water temperature $\left(12\right.$ to $\left.25{ }^{\circ} \mathrm{C}\right)$ recommended by WHO (2008). The temperature of water does not have a direct impact on the man's health. However, temperature values above $20{ }^{\circ} \mathrm{C}$ enhance the development of microorganismes of the environment, so increase in the water temperature creates conditions favorable to the degradation of water quality, in particular those related to microorganisms (Rodier, 2009). Indeed, our study site is situated in an area with an average annual temperature estimated at $28.3{ }^{\circ} \mathrm{C}$. Rise of the temperature of water samples can be explained by the impact of ambient temperature, localization of the watertable, sampling hour and season. The lower and higher limits of salinity of water analyzed were respectively $79.2 \mathrm{ppm}$ ( $\mathrm{F} 1$ borehole) and $970.3 \mathrm{ppm}$ (F17 borehole). The variations of the salinity values can be explained by the contamination of water. Contamination sources would be the proximity of these boreholes with latrines. TDSs levels of water samples oscillated between 119.4 and $1331.3 \mathrm{mg} / \mathrm{l}$. They have been correlated to the electrical conductivity and the salinity. The variations of the TDSs concentrations would be due to mineralization. The increase of TDSs can be explained by the decomposition of the organic matters of water by the microorganismes that frees mineral substances contributing to their growth (Djaouda et al., 2014). The concentration of dissolved $\mathrm{CO}_{2}$ has high value at borehole F4 $(27.8 \mathrm{mg} / \mathrm{l})$ and low value at borehole F2 $(9.5 \mathrm{mg} / \mathrm{l})$. The solubility of the carbon dioxide in water depends on the partial pressure of the gases in the atmosphere and the temperature of water (Rodier, 2009).

The values of bacterial abundance of water samples showed that all water samples were contaminated by the HAMB. The higher value was $155 \mathrm{CFU} / \mathrm{ml}$ (borehole F10) and the lower value was $23 \mathrm{CFU} / \mathrm{ml}$ (borehole F12). This pollution could be assigned to poor protection of borehole, failure to respect protective perimeter and absence of suitable sanitation system (Gomdje et al., 2015). Total coliforms and E. coli were detected in $72.22 \%$ of boreholes water samples, with abundance oscillating respectively between 4 CFU/100 $\mathrm{ml}$ (F7) and $203 \mathrm{CFU} / 100 \mathrm{ml}$ (F3), and 3 CFU/100 ml (F7) and $172 \mathrm{CFU} / 100 \mathrm{ml}$ (F3). This abundance exceeded the WHO standard for drinking water $(0 \mathrm{CFU} / 100 \mathrm{ml})$. Presence of $E$. coli, group of bacteria living in intestines of mammals indicates recent feacal pollution by various sources, as latrines or animal 
wastes (Gerba, 2009). It is very important to note that the quality of these boreholes water is not satisfactory because of total coliforms and E. coli contamination which could usually indicate the potential presence of pathogenic microorganisms and opportunistic pathogenic bacteria such as Salmonella $s p$, Shigella $s p$, Vibrio cholerae, Pseudomonas sp, responsible for numerous waterborne diseases. Boreholes contaminated by $E$. coli and total coliforms were close to latrines, waste waters, dumps and mayos. The poor quality of these borehole waters could be attribuated to poor protection of borehole and failure to respect the protective perimeter. Besides, the contamination of the water table of boreholes depends on the soil permeability (Pitkänen et al., 2011). The spatial variations of the concentration of the bacterio-pollutants could also be explained by the variations of the potentialities of retention of the bacteria by the particles of soil (Nola et al., 2006). Boreholes F1, F4, F9 and F17 did not present any bacterial indicator of feacal contamination, although they have at least one potential source of pollution. This exception would be explained by the degree of soil permeability and/or the position of the potential sources of pollution in relation with the sense of outflow of the watertable. The other origin could be the variations in abiotic properties of percolating water. These properties impact the transfer of the bacteria from the soil surface toward the watertable (Nola et al., 2006). Borehole F6 was also not contaminated by the total coliforms and $E$. coli. Similar findings have been reported in other areas of Africa (Ince et al., 2010; Arnold et al., 2013). Indeed, no potential source of pollution has been found at its vicinity; therefore this borehole would be effectively safe from feacal contamination.

\section{Conclusion}

This study aimed at assessing the bacteriological quality of borehole waters intended for human consumption in Maroua. It revealed that all the analyzed water samples contained HAMB and $72.22 \%$ of boreholes are contaminated by E. coli and the total coliforms. The physico-chemical parameters showed that boreholes water have low to high mineralization. The water $\mathrm{pH}$ varied from acidic to basic. The contamination of borehole waters by bacterial indicators of feacal pollution would be due to soil properties that encourage the infiltration of waste water coming from the septic tanks, of solid waste dumpsites located close to the boreholes and by lack of maintenance of boreholes and the position of the potential sources of pollution in relation with the sense of outflow of the groundwater. It is very important to treat borehole waters before consumption. The equipment of the city with water purification facilities, the interdiction of anarchical release of waste water and the regular monitoring of groundwater quality could significantly reduce the degree of bacteriological contamination of borehole waters of the study region.

\section{COMPETING INTERESTS}

The authors declare that they have no competing interests.

\section{AUTHORS' CONTRIBUTIONS}

This work was carried out in collaboration between all authors. MD designed the study, performed the statistical analysis, and wrote the protocol. MD and SLwrote the first draft of the manuscript. AL, MKM, Zoua Wadoubé managed the analyses of the study. MN and TN managed the literature searches. All authors read and approved the final manuscript.

\section{ACKNOWLEDGMENTS}

The authors wish to thank Dr Nguihdama for mapping the sampling sites.

\section{REFERENCES}

Amadou H, Laouali MS, Manzola A. 2014. Analyses physico-chimiques et bactériologiques des eaux de trois aquifères de la région de Tillabéry: Application des méthodes d'analyses statistiques multivariées. Larhyss Journal, 20: 25-41.

APHA (American Public Health Association). 2012. Standard Methods for the Examination of Water and Wastewater 
( $22^{\text {nd }}$ edn). American Public Health Association/American Water Works Association/Water Environment Federation: Washington, DC, USA.

Arabi M, Xiao N, Taiwe KD, Liang S. 2014. Cholera incidence in the Far North Region of Cameroon: a geographic perspective. AJOSS, 5(3): 141-156.

Arnold M, VanDerslice JA, Taylor B, Benson S, Allen S, Johnson M, Kiefer J, Boakye I, Arhinn B, Crookston BT, Ansong D. 2013. Drinking water quality and source reliability in rural Ashanti region, Ghana. $J$ Water Health, 11(1): 161-172. DOI: 10.2166/wh.2013.104

Ashbolt NJ, Grabow OK, Snozzi M. 2001. Indicators of microbial water quality. In Water Quality: Guidelines, Standards and Health, Fewtrell L, Bartram J, (eds). World Health Organization (WHO), IWA Publishing: London, UK; 289-316.

Bartram J, Cotruvo J, Exner M, Fricker C, Glasmascher A. 2003. Heterotrophic Plate Counts and Drinking-Water Safety. World Health Organization: London.

Belghiti M L, Chahlaoui A, Bengoumi D, El Moustaine R. 2013. Etude de la qualité physico-chimique et bactériologique des eaux souterraines de la nappe plioquaternaire dans la région de Meknes (Maroc). Larhyss Journal, 14: 21-36.

BUCREP (Bureau Central des Recensements et des Etudes de Population) 2017. Troisième recensement général de la population et de l'habitat : Analyse thématique, population en chiffre. http://www.bucrep.cm/index.php/fr/rece nsements/3eme-rgph/resultats/20-3emergph/presentation. Accessed 11 June 2017.

Djaouda M, Njine T, Liang S, Ebang Menye D, Gaké B, Zebaze Togouet SH, Nola M. 2014. Bacteriological quality of well waters in Garoua. Wat Qual Expo Health, 6: 161-176. DOI: 10.1007/s 12403-014-0120-Z.

Djuikom E, Njine T, Nola M, Sikati V, Jugnia LB. 2006. Microbiological water quality of the Mfoundi River watershed at Yaoundé, Cameroon, as inferred from indicator bacteria of fecal contamination. Environ Monit Assess., 122(1-3): 17183.

Dovonou FE, Alassane A, Adjahossou VN, Agbodo B, Djibril R, Mama D. 2017. Impacts de l'assainissement autonome sur la qualité des eaux de puits dans la Commune de Sèmè-Podji (Sud-Bénin). Int. J. Biol. Chem. Sci. 11(6): 3086-3099. DOI:

https://dx.doi.org/10.4314/ijbcs.v11i6.42

Gerba CP. 2009. Indicator Microorganisms. In Environmental Microbiology. Academic Press Inc.: San Diego, CA; 485-499.

Gomdje H V, Ndongo ES, Ombolo A, Loura B. 2015. Bacteriological and Physicochemical Characterization of Water from Wells in Urban areas of the District of Maroua III (Far North Cameroon). Int. J. Curr. Trends Eng. Technol., 1(2): 43-50.

Gorham TJ, Yoo J, Garabed R, Mouhaman A, Lee J. 2017. Water access, sanitation, and hygiene conditions and health outcomes among two settlement types in rural Far North Cameroon. Int. J. Environ. Res. Public Health, 14(441). DOI: 10.3390/ijerph14040441.

Healy Profitos JM, Arabi M, Lee S, Garabed R, Moritz M, Piperata B, Tien J, Bisesi M, Lee J. 2014. Muddying the waters: a new area of concern for drinking water contamination in Cameroon. Int $J$ Environ Res Public Health, 11(12): 12454-12472.

Holt JG, Krieg NR, Sneath PHA, Staley JT, Williams ST. 2000. Bergey's Manual of Determinative Bacteriology $\left(9^{\text {th }}\right.$ edn). Lippincott Williams and Wilkins: Philadelphia.

Hounsounou EO, Agassounon DTM, Kelome NC, Vissin EW, Mensah GA, Agbossou E. 2016. Pollution des eaux à usages domestiques dans les milieux urbains défavorisés des pays en développement: Synthèse bibliographique. Int. J. Biol. Chem. Sci., 10(5): 2392-2412. http://dx.doi.org/10.4314/ijbcs.v10i5.35

Ince $\mathrm{M}$, Bashire $\mathrm{D}$, Oni $\mathrm{O}$, Awe $\mathrm{E} \mathrm{O}$, Ogbechie V, Korve K. 2010. Rapid 
Assessment of Drinking water Quality in the Federal Republic of Nigeria. Country Report of the Pilot Project Implementation in 2004-2005. WHO, Geneva, Switzerland.

Kirschner AKT, Kavkaa GG, Velimirov B, Mach RL, Sommer R, Farnleitner AH. 2009. Microbiological water quality along the Danube River: integrating data from two whole-river surveys and a transnational monitoring network. Water Res., 43(15): 3673-3684

Mkandawire T. 2008. Quality of groundwater from shallow wells of selected villages in Blantyre District, Malawi. Phy Chem Earth, 33: 807-811.

Negera E, Nuro G, Kebede M. 2017. Microbiological assessment of drinking water with reference to diarrheagenic bacterial pathogens in Shashemane Rural District, Ethiopia. African Journal of Microbiology Research, 11(6): 254-263.

Ngwe E, Banza-Nsungu AB. 2007. Les déterminants socio-environnementaux de la morbidité diarrhéique des enfants de moins de 5 ans en milieu urbain au Cameroun: les villes d'Ebolowa et Maroua. Projet réalisé dans le cadre du Programme international de recherche sur les interactions entre la population, le développement et l'environnement (PRIPODE) coordonné par le CICRED, Rapport final de recherche. http://pripode.cicred.org/IMG/pdf_CM1FinalReport.pdf. Accessed 11 June 2017.

Nola M, Njiné T, Kemka N, Zébazé TSH, Servais P, Messouli M, Boutin C, Monkiédje A, Foto Menbohan S. 2006. Transfert des bactéries fécales vers une nappe phréatique à travers une colonne de sol en région équatoriale : influence de la charge en eau appliquée en surface. Rev. Sci. Eau, 19: 101- 112.

Nouayti N, Khattach D, Hilali M. 2015. Evaluation de la qualité physicochimique des eaux souterraines des nappes du Jurassique du haut bassin de Ziz (Haut Atlas central, Maroc). J. Mater. Environ. Sci., 6(4) : 1068-1081.
Páll E, Niculae M, Kiss T, Şandru CD, Spǐnu M. 2013. Human impact on the microbiological water quality of the rivers. Journal of Medical Microbiology, 62: $1635-1640$.

Pitkänen $\mathrm{T}$, Karinen $\mathrm{P}$, Miettinen IT, Lettojärvi H, Heikkilä A, Maunula R, Aula V, Kuronen H, Vepsäläinen A, Nousiainen L-L, Pelkonen S, HeinonenTanski H. 2011. Microbial contamination of groundwater at small community water supplies in Finland. Ambio., $\quad 40$ : $\quad 377-390 . \quad$ DOI: 10.1007/s13280-010-0102-8

Rodier J. 2009. L'Analyse de l'Eau $\left(9^{\mathrm{e}}\right.$ édition). Dunod : Paris, France.

Sighomnou D, Sigha NL, Lienou G. 2002. La plaine du Yaéré dans le NordCameroun, une expérience de restauration des inondations: gestion intégrée des ressources naturelles en zones inondables. Rapport des colloques et séminaires, Paris, France, 375-384.

Sobsey MD. 2002. Managing Water in the Home: Accelerated Health Gains from Improved Water Supply. World Health Organization Sustainable Development and Healthy Environments. World Health Organization, Geneva, WHO/SDE/WSH/02.07.

WHO (World Health Organization). 2003. Iron in Drinking Water: Background Document for Development. World Health Organization guidelines for drinking water quality: Geneva, Switzeland.

WHO (World Health Organization). 2008. Guidelines for Drinking-water Quality, $\left(3^{\text {rd }}\right.$ edn), incorporating the first and second Addenda, Recommendations. WHO: Geneva, Switzerland.

WHO (World Health Organization). 2014. Preventing Diarrhoea Through Better Water, Sanitation and Hygiene: Exposures and Impacts in Low and Middle-Income Countries. WHO: Geneva, Switzerland. 